\title{
Application of Politeness Principle in the Teacher-students Communication in College English Teaching in China
}

\author{
Xiang-wu Li \\ Department of Foreign Languages, Ankang University, Ankang, Shaanxi, China
}

\begin{abstract}
Politeness Principle (PP) by Leech, as a basic theory of pragmatic study, is paid more attention by many linguistic scholars. It is the principle of language communication established between two sides' interaction, and it ultimately serves language communication. The application of tact maxim, approbation maxim and agreement maxim of PP in college English classes between teacher-students communication will help to create a harmonious and warm atmosphere of teaching and to improve students' interest in English learning.
\end{abstract}

Index Terms - Politeness Principle; teacher-students communication; college English teaching

\section{Introduction}

In his main book, Principles of Pragmatics, Geoffrey Leech (1983) formulates 'Politeness Principle' (PP for short), trying to remedy Grice's Cooperative Principle which is presumed to be unable to interpret, for instance, why people are prone to use indirect ways of saying things. To Leech, it is politeness that motivates it. Politeness principle is one of pragmatic principles; it is a principle of the language communication established between the two sides' interaction; and it ultimately serves language communication.

According to Leech, there is a politeness principle with conversational maxims similar to those formulated by Paul Grice. He lists six maxims: tact maxim, generosity maxim, approbation maxim, modesty maxim, agreement maxim, and sympathy maxim.

In college English teaching in China, friendly teacherstudents communication is one of the important qualities to improve class teaching. In communication, if teachers and students can make good use of Politeness Principle, they can get achievement in communication.

Here in this paper, three maxims of PP, including the tact maxim, the approbation maxim and the agreement maxim, will be discussed to be applied into the teacher-students communication in college English classes. It will help to find a more effective language teaching model, to establish a more harmonious relationship between teachers and students, to create a harmonious and warm atmosphere of teaching and improve students' interest in learning English. It will enhance students' self-confidence, so as to achieve effective teaching in college English teaching.

\section{Application of PP in the Teacher-student Communication in College English Classes}

In college English classes, due to the development of students' self-awareness, college students experience selfesteem, self-love and other feelings very strongly and sensitively. They strive to maintain such experience, and hope others' actions adapt to their requests. If the teacher in class satisfies students' self-esteem, students are willing to accept the requests and expectations which the teacher brings forward; otherwise, they will have some resistance. Therefore, the teacher should effectively use PP so that students feel positive expectations of their teacher. It will help students increase self-confidence, and strive to improve academic performance and form close relationships with teachers. Otherwise, students can produce psychological conflict; they will give up efforts and give themselves up, and gradually feel estranged from their teachers.

Facing such a situation, teachers should take some measures to create a harmonious teacher-students relationship in college English classes. The application of PP can help establish a good teachers-students relationship and promote the effective teacher-students exchange, stimulate students' interest to learn, and enhance students' motivation to learn English, so as to make students master English language skills better.

\section{A. The application of the tact maxim}

According to Leech (1983), the Tact maxim states: "Minimize the expression of beliefs which imply cost to other; maximize the expression of beliefs which imply benefit to other." The first part of this maxim fits in with Brown and Levinson's negative politeness strategy of minimizing the imposition, and the second part reflects the positive politeness strategy of attending to the hearer's interests, wants, and needs.

The tact maxim is the highest maxim of PP. And it is also used widely and is the most indispensable maxim. In college English classes, whether the application of teacher language is appropriate or not directly affects the success or failure of teaching activities (Wang Hong, 2008).

In class, if the teacher uses some appropriate and polite languages together whit proper communicative strategies, the class atmosphere would be comfortable and harmonious. (Chen Yingcong \& Huang Yan, 2009)

For example, in a college English class, if some students do not participate in or be reluctant to participate in teachersstudents interaction, the teacher may express as follows:

\section{A: You must take part in it. \\ B: Could you take part in it? \\ C: Would you take part in it, please?}

From the above, it is clear that the teacher's tone of A is stiff, by ordering students to perform this action. His words hurt students' initiative. $\mathrm{C}$ is the most polite way in encouraging students to speak. Hearing such words, even if 
students do not want to participate in this activity, they will also actively cooperate with the teacher.

In a certain language situation, a lot of expression styles can be used in the teacher-students communication. Different expression styles will affect the teacher-students communication differently. For instance,

D: Speak slowly! I can't hear you clearly.

E: I'm sorry, but I didn't catch your words. Would you mind repeating what you said?

$\mathrm{F}$ : Someone cheated in the exam.

G: Someone depended on others in the exam.

From above, it is obvious that teachers use different language and tone will make students come into being different feeling when expressing the same idea. Sentences D and $\mathrm{F}$ are direct and out of considering students' feeling, which makes students generate failure. However, sentences E and $\mathrm{G}$ are in accordance with politeness and tact maxim. On the one hand, it makes students understand teacher's intention and transfer teacher's suggestions or criticism. On the other hand, it protects students' face. Thus, teachers-students communication can go on successfully. And the teaching in class can be improved effectively.

In teacher-students communication, whether application of teacher's speech is appropriate or not has become a key issue influencing teachers-students communication. In college English classes, students are often afraid of the teacher's questions. To overcome such mentality, teachers can question indirectly. Usually, the teachers make positive feedback to students' answers. When students answer questions, the teachers can praise and recognize the students' answers. This can stimulate the enthusiasm of the students. However, if students cannot answer questions, the teacher's negative feedback manner will discourage the students' activity. So the teacher's speeches play an important role in the success of teacher-students communication. The tact maxim helps to bring into role of teachers' speech. The teacher can use tact maxim to stimulate students' interest to learn, enhance motivation to learn, so as to make students master language skills better.

The application of tact maxim will make students feel that they are respected. Availability of teacher's language will make students remove fear so that they can speak out and dare to ask questions in class.

\section{B. The application of the approbation maxim}

According to Leech (1983), the Approbation maxim states, "Minimize the expression of beliefs which express dispraise of other; maximize the expression of beliefs which express approval of other." The first part of the maxim avoids disagreement; the second part intends to make other people feel good by showing solidarity.

In the teacher-students communication, the teacher should make more use of praise-style discourses, which can comply with the approbation maxim of politeness principle. The pragmatic characteristics of western politeness principle is never mean to people with good performance over-praised, such as "perfect job, great done" and so on; even when the performance of students is unsatisfactory, the teacher should also use such expressions as "What you said is quite good, but I think there is still some places to improve" to encourage students. Except using language directly to express, the teacher can also use body language to achieve this purpose, for example, listening to students to answer questions with a smile, nodding or using eyes to communicate with students. With the teacher's praise, students will get more enthusiasm and interest, and be more active, rather than passive, to learn.

In the real life, every person wants to be respected and praised. Westerners praise others more likely than Chinese; they never mean their praise words, such as the "perfect man, great job" and so on. In college English classes, even if students answer questions poorly, the teacher can not directly criticize students either. Instead, the teacher would say such as "what you have done are very good, but you can do it better" to encourage students (Zhang Hongyu, 2008). In addition, the teacher should pay attention to eye contacts with students in class, to make students feel that their teacher concerns about them.

When a student cannot answer the teacher's questions in class, the teacher's words will affect students' activities directly. For example,

A: Why cannot you answer this simply question, it's so easy to answer!

B: You can just try, please! I believe you can do well! Come on!

From the above expressions, it is clear that $\mathrm{A}$ is rude. The teacher will make students lose confidence. However, B is very polite and useful, and by using $B$, the teacher can encourage students to answer questions confidently. Students will feel that even if they do not do well, the teacher cannot criticize them. The second expression may create a harmonious teachers-students relationship. After students answer questions, the teacher should make a relevant judgment by using expressions of different levels such as "excellent, wonderful, well done, very good, good" to arouse students' activities.

What's more, after students answer questions, the teacher should also give an appropriate reflection. Firstly, the teacher needs to confirm students' answers actively. The teacher can use the language, smile, nod or eye contacts and other language forms to express certain meanings. Also the teacher should be careful not to over-praise each student who answers in case that students doubt the authenticity of the teacher's evaluation. If students' answers to questions are incomplete or lack in depth, the teacher can guide students to make further answers by using the following questions: Any more? Could you please develop your ideas further? Can you provide an example of that concept?

In this way, the application of approbation maxim can enhance students' self-confidence and evoke students' activities or enthusiasm.

\section{The application of the agreement maxim}

According to Leech (1983), the Agreement maxim runs as follows: "Minimize the expression of disagreement between self and other; maximize the expression of agreement between self and other." It is in line with Brown and Levinson's 
positive politeness strategies of 'seek agreement' and 'avoid disagreement,' to which they attach great importance. However, it is not being claimed that people totally avoid disagreement. It is simply observed that they are much more direct in expressing agreement, rather than disagreement.

Reducing differences, both teaching and learning will improve. The teacher should choose to reduce distance with students in class, and should remain consistent with students. Thus, the teacher is easy to build harmonious relations with students, which is good to conduct smooth progress of class teaching.

The core of the agreement maxim is to minimize the expression of disagreement between self and other. The study of pragmatics states that when communicative position of all people is close to and the value is consistent, the quest or order of one person is easy to be accepted by the other. In the teacher-students communication, when some different ideas between the teacher and students appear, the teacher can apply the agreement maxim, for example, by using the following expressions: I totally agree with you. / I think your answer is completely right. / The answer is completely right. These expressions will reduce inconsistence and add consistence of language between the teacher and students. In college English classes, teachers should encourage students to speak more and express their different ideas so as to improve English teaching quality (Liu Yaoyao \& Li Duanqi, 2008).

The teacher should try to shorten the distance and maintain consistency in class utterances and behaviors with students by using the agreement maxim of PP, which will be helpful for building harmonious relations and conducive to smooth progress of teaching in class. When students express opinions on a problem, the teacher should focus on what is affirmed, such as "Yes, I agree with you on this point". The teacher affirms each other's views first, and then launches his/her own different view such as "but, I think ...", which may increase the agreement and consistency with students, to ensure the maximum degree of the agreement between the two sides in communication in college English classes.

The agreement maxim reduces inconsistencies between the teacher and students, which will be more conducive for the teacher to encourage students to express different ideas, and then exchange friendly, so as to enhance the effectiveness of teaching. In college English classes, the teacher should encourage students to express their views, as long as is justified; the teacher should agree, and not force the idea of students consistent with their own. The agreement maxim not only embodies the respect of the teacher to students, but also enhances students' confidence, and at the same time, encourages other students to express their views courageously.

\section{Conclusion}

Nowadays, students' self-esteem is very strong, which requires teachers to take some communication strategies to exchange with students friendly in class. In a college English class, whether teachers-students relationship is good or not may directly impact on students' achievement in English learning. With a good teacher-students relationship, students will perhaps love their teacher, and then they will like this course and will study this course better than before. On the contrary, students will produce to contradict with the teacher, and then they will hate the course which the teacher takes. The appropriate application of PP in college English teaching can reduce students' anxiety and the frustration. It helps to ease the class atmosphere, so as to achieve an effective teaching. In college English classes, whether teachers' language is polite or not plays a crucial role on the effectiveness of teaching. Therefore, PP is suggested to be used in college English teaching. The application of PP reasonably in the class communication may help to narrow the distance between the teacher and students, make students feel that the teacher is affable and easy to communicate, and establish a harmonious relationship between teachers and students, so as to improve college English teaching in China.

\section{References}

[1] Leech, G. Principles of Pragmatics. London, New York: Longman Group Ltd., 1983.

[2] Wang Hong. "The application of politeness principle in college oral English teaching", Science \& Technology Information, vol. 9, p. 4, 2008.

[3] Chen Yingcong, Huang Yan. "The application of politeness principle in teaching college English in class", Journal of Sichuan University of Science and Engineering, vol. 9, pp. 2-3, 2009.

[4] Zhang Hongyu. "The application of politeness principle in English classrooms", Journal of Mudanjiang University, vol. 8, p. 5, 2008.

[5] Liu Yaoyao, Li Duanqi. "Application of politeness principle in the teaching of college oral English", Journal of Hubei Normal University, vol. 5, p. 3, 2008. 